\title{
Athelia singularis and Leptosporomyces mundus (Basidiomycota) new to Finland
}

\section{Panu Kunttu ${ }^{1 *}$, Matti Kulju ${ }^{2} \&$ Heikki Kotiranta ${ }^{3}$}

\author{
${ }^{1}$ University of Eastern Finland, School of Forest Scienes, P.O. Box 111, FI-80101 Joensuu, Finland \\ ${ }^{2}$ Ylispuuntie 13, FI-90420 Oulu, Finland \\ ${ }^{3}$ Finnish Environment Institute, P.O. Box 140, FI-00251 Helsinki, Finland
}

Received 3 March 2016 / Accepted 30 March 2016 / Published 4 April 2016

Kunttu, P., Kulju, M. \& Kotiranta, H. 2016. Athelia singularis and Leptosporomyces mundus (Basidiomycota) new to Finland. - Mycobiota 6: 29-37. doi: 10.12664/mycobiota.2016.06.03

\begin{abstract}
The first Finnish records of Athelia singularis and Leptosporomyces mundus (Basidiomycota) are reported and notes of their habitats and substrata are given. The descriptions of the species are presented as well as their microscopical drawings. The taxonomy of two species is briefly discussed. The new records derived from Northern Finland, Rovaniemi, Pisavaara Strict Nature Reserve.
\end{abstract}

Key words: aphyllophoroid fungi, Athelia, biogeography, corticioid, distribution, Finland, fungal diversity, Leptosporomyces

\section{Introduction}

The knowledge of corticioid species in Finland has improved a lot after the first comprehensive checklist of Finnish aphyllophoroid fungi (Kotiranta et al. 2009). It listed altogether 980 aphyllophoroid species and 422 corticioid species from Finland. Since then, many corticioid species new to Finland have been found (e.g. Kunttu et al. 2010, 2011, 2012; Kotiranta et al. 2011; Kotiranta \& Larsson 2013; Kotiranta \& Shiryaev 2013). In this article two corticioids, Athelia singularis and Leptosporomyces mundus, are reported for the first time from Finland, Pisavaara Strict Nature Reserve.

Pisavaara Strict Nature Reserve was founded in 1938 and it covers an area of 4887 hectares $(70 \%$ of this area is forest). The naturalness of Pisavaara forests is high, since no loggings have been done after 1924. The volume of dead wood is on average $55 \mathrm{~m}^{3}$ $\mathrm{ha}^{-1}$ with range $40-70 \mathrm{~m}^{3} \mathrm{ha}^{-1}$ (Niemelä et al. 2005), which is remarkable high amount, compared to the typical situation in Finland nowadays: in nature conservation areas the

\footnotetext{
*Corresponding author: e-mail: panu.kunttu@uef.fi
} 
volume of dead wood is approximately $10 \mathrm{~m}^{3} \mathrm{ha}^{-1}$ and in managed forests only $5.7 \mathrm{~m}^{3} \mathrm{ha}^{-1}$ (Hokkanen et al. 2005; Juntunen 2014).

Pisavaara is one of the best polypore-surveyed forest areas in Finland, and the oldest species inventories have been carried out there already decades ago (Teivainen 1949; Eriksson $\&$ Strid 1969). Niemelä et al. (2005) listed 125 polypore species from Pisavaara, and this is the highest number of polypores reported from any forest area in Finland. The species list includes many very rare and threatened polypore species, like Inonotopsis subiculosa (Peck) Parmasto, Favolus pseudobetulinus (Murashk. ex Pilát) Sotome \& T. Hatt., Postia balsamina Niemelä \& Y.C. Dai, Pycnoporellus alboluteus (Ellis \& Everh.) Kotl. \& Pouzar and Antrodiella canadensis (Overh.) Niemelä (Niemelä et al. 2005).

\section{Material and methods}

On 12 October 2015, Matti Kulju (MK) and Axel Kroschel (AK) collected specimens of aphyllophoroid fungi in Pisavaara Strict Nature Reserve in the municipality of Rovaniemi, Northern Finland (Fig. 1). The study area is situated in Ostrobottnia ultima biogeographical province in the Middle Boreal zone, SW Lapland (Ahti et al. 1968; Anonymous 2014).

The applied inventory method in this study was opportunistic sampling of species, and specimens were collected only discretionarily (Stokland \& Sippola 2004). The code after the collector's abbreviation is a personal sampling number of the specimen. Voucher specimens are deposited in the herbarium of the University of Oulu (OULU) and in the reference herbarium of Heikki Kotiranta (H.K.).

The decay stage classification (1-5) of tree trunks is in accordance with Renvall (1995), where stage 1 means hard, recently dead wood and 5 completely decayed wood. Trunk diameters were measured at the point where fruit bodies grew. For the examined specimens, we used four levels for the names of sites: biogeographical province, municipality, area, and topographical name. For coordinates, we used the Finnish National Uniform Coordinate System (UCS, $27^{\circ}$ E) (Heikinheimo \& Raatikainen 1981). Nomenclature of corticioid species follows Jülich (1972).

Thirty spores per specimen were measured in Cotton Blue (CB). The other mounting media used were: Melzer's reagent (MLZ) and 5\% potassium hydroxide $(\mathrm{KOH})$. The following abbreviations are used: $\mathrm{L}=$ mean spore length, $\mathrm{W}=$ mean spore width, $\mathrm{Q}=$ range of the variation in $\mathrm{L} / \mathrm{W}$ ratio, $\mathrm{Q}^{*}$ = quotient of the mean spore length and the mean spore width $(\mathrm{L} / \mathrm{W})$. None of the measurements derive from a spore print.

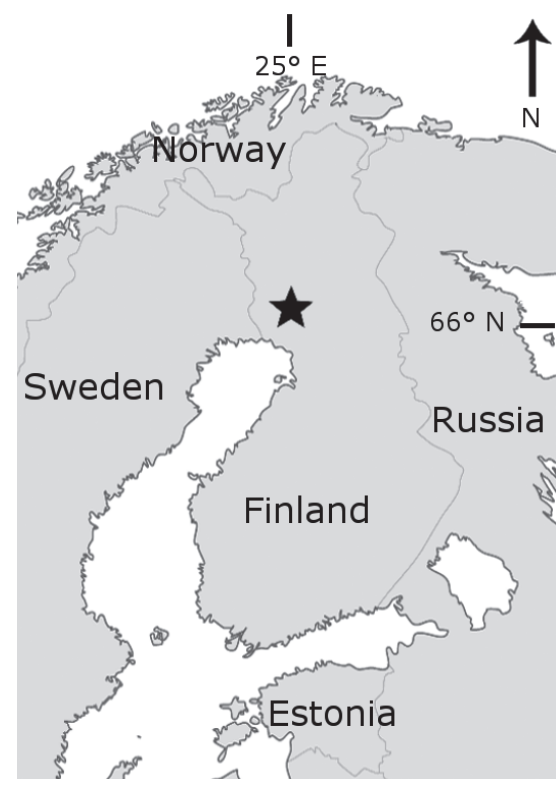

Fig. 1. Geographic location of the study area 


\section{Results and discussion}

Athelia singularis Parmasto, Eesti NSV Teaduste Akadeemia Toimetised, Bioologia 16(4): 382, 1967.

Fruit body resupinate, pellicular (athelioid), smooth, easily detachable, fairly thin with very thin subiculum, white or slightly cream-coloured, margin not differentiated.

Hyphal system monomitic, all hyphae constantly clamped. Subicular hyphae thinwalled, 3-4(-5) $\mu \mathrm{m}$ in diameter; subhymenial hyphae thin-walled, 2.5-3.5(-4) $\mu \mathrm{m}$ wide. Cystidia none, but finger-like hyphidia, 19-26 × 3-4 $\mu \mathrm{m}$ relatively common between basidia. Basidia clavate, basally clamped, stalked, thin-walled, 24-31 × 6.5-8 $\mathrm{m}$ (in CB), swelling in $\mathrm{KOH}, 24-33 \times 7-12 \mu \mathrm{m}$, with four, up to $8.5 \mu \mathrm{m}$ long stout sterigmata. Spores ellipsoid, thin-walled, CB, MLZ-, often glued in pairs - tetrads, (7.7-)7.9-10(-10.2) $\times$ (4.2-)4.4-5.5(-6.3) $\mu \mathrm{m}, \mathrm{L}=8.5 \mu \mathrm{m}, \mathrm{W}=5 \mu \mathrm{m}, \mathrm{Q}=1.5-1.9, \mathrm{Q}^{*}=1.7$, with a relatively prominent apiculus.

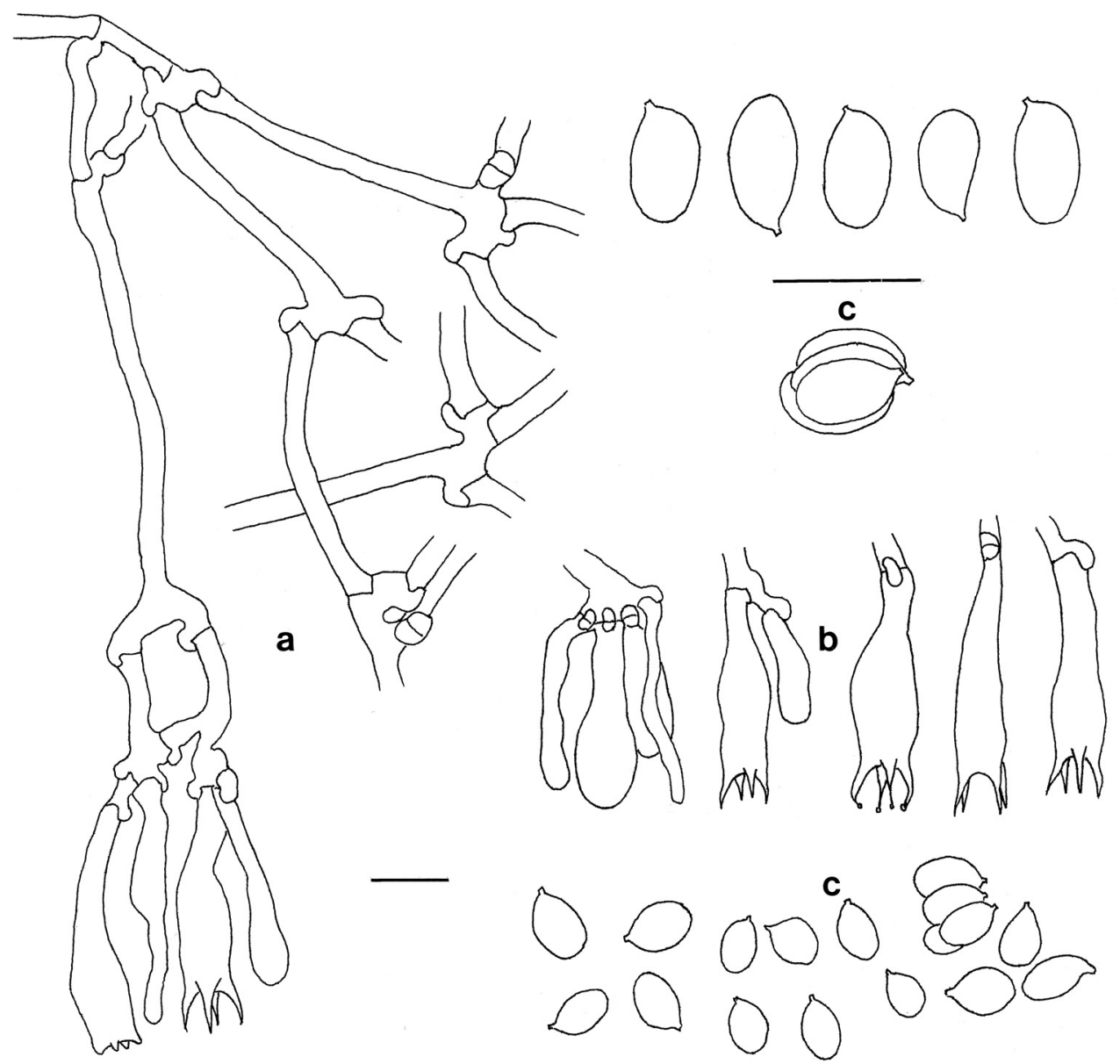

Fig. 2. Athelia singularis: a) section through basidiocarp, b) basidioles, basidia and hyphidia, c) spores (Kulju 104/15). Scale bars $=10 \mu \mathrm{m}$ 


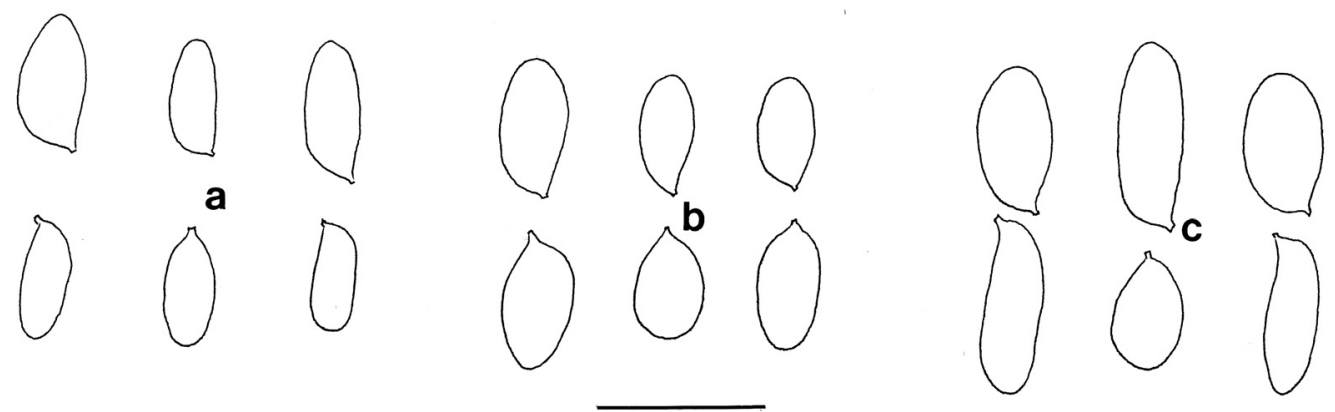

Fig. 3. Spores of Athelia fibulata: a) Kotiranta 16664, b) Kotiranta 12533a, c) Kotiranta 25123. Scale bar $=10 \mu \mathrm{m}$

The other constantly clamped Athelia with relatively large spores is A. fibulata Christ. (Fig. 3). It is one of the most common Athelia species in Finland and differs from $A$. singularis mostly by its smaller basidia and narrower, differently shaped spores (Fig. 3). We studied three specimens of $A$. fibulata for comparison: two from Finland and one from Russia (see below). The Finnish specimens are fairly uniform with each other: basidia are clavate to subcylindrical, often stalked and not swelling in $\mathrm{KOH}$, (14-) 15-21(-23) $\times(5.5-) 6-7 \mu \mathrm{m}$, with four, up to $5 \mu \mathrm{m}$ long sterigmata. Spores are cylindrical to subfusiform, sometimes ellipsoid, thin-walled, CB-, MLZ-, often glued in pairs-tetrads, 6.5-8.8(-9.5) $\times(2.8-) 3.1-4.2(-4.8) \mu \mathrm{m}, \mathrm{L}=7.5 \mu \mathrm{m}, \mathrm{W}=3.9 \mu \mathrm{m}$, $\mathrm{Q}=1.6-2.7, \mathrm{Q}^{*}=2$, with a small apiculus. The Russian specimen deviates from the Finnish material: the basidia are about of the same size as in $A$. singularis, viz. (20.5-)22-30 $\times 7-8 \mu \mathrm{m}$, with four, up to $6.5 \mu \mathrm{m}$ long sterigmata. Spores are ellipsoid or cylindrical, normally tapering apically and often glued together, (8-)8.2-10.5(-14) $\times 3.6-5.1(-5.4) \mu \mathrm{m}, \mathrm{L}=9.2 \mu \mathrm{m}, \mathrm{W}=4.4 \mu \mathrm{m}, \mathrm{Q}=1.7-3, \mathrm{Q}^{*}=2.1$, with a small apiculus. The shape of the spores is more or less typical for $A$. fibulata, but they are abnormal large like the basidia. However, we believe that also the Russian specimen belongs to $A$. fibulata, especially because of the shape of the spores. According to Jülich (1972), the basidia of $A$. fibulata are 16-20 $\times 6-8 \mu \mathrm{m}$ and of A. singularis 22$30(-40) \times 7.5-8.5(-11.5) \mu \mathrm{m}$ and the spores of the latter $(8-) 12(-14) \times 5-6 \mu \mathrm{m}$ with a prominent ("deutlich") apiculus. In Parmasto's (1967) description the spores are slightly smaller, 7.5-10 × 5-6 $\mu \mathrm{m}$, fitting well with the Finnish specimen. It seems that basidia size is not as good separating characteristic between $A$. fibulata and $A$. singularis as spore shape. Athelia fibulata has mostly spores which are tapering towards the apex, small apiculus and the $\mathrm{Q}$ value around two, while the spores of $A$. singularis are apically roundish, with a prominent apiculus and the $\mathrm{Q}$ value is less than two.

Specimen examined-FINLAND, OSTROBOTTNIA ULTIMA, Rovaniemi, Pisavaara Strict Nature Reserve, Teerilamu, UCS 7357519:3414948, alt. 205 m, 12 Oct 2015, leg. MK 104/15 (OULU, H.K.) \& AK, det. MK, conf. HK 2015. Fruit body grew underneath of the decorticated trunk of Pinus sylvestris L. (diameter $12 \mathrm{~cm}$, decay stage 4). The trunk was situated in a sparse pine forest beside of a boulder field (Fig. 4). 


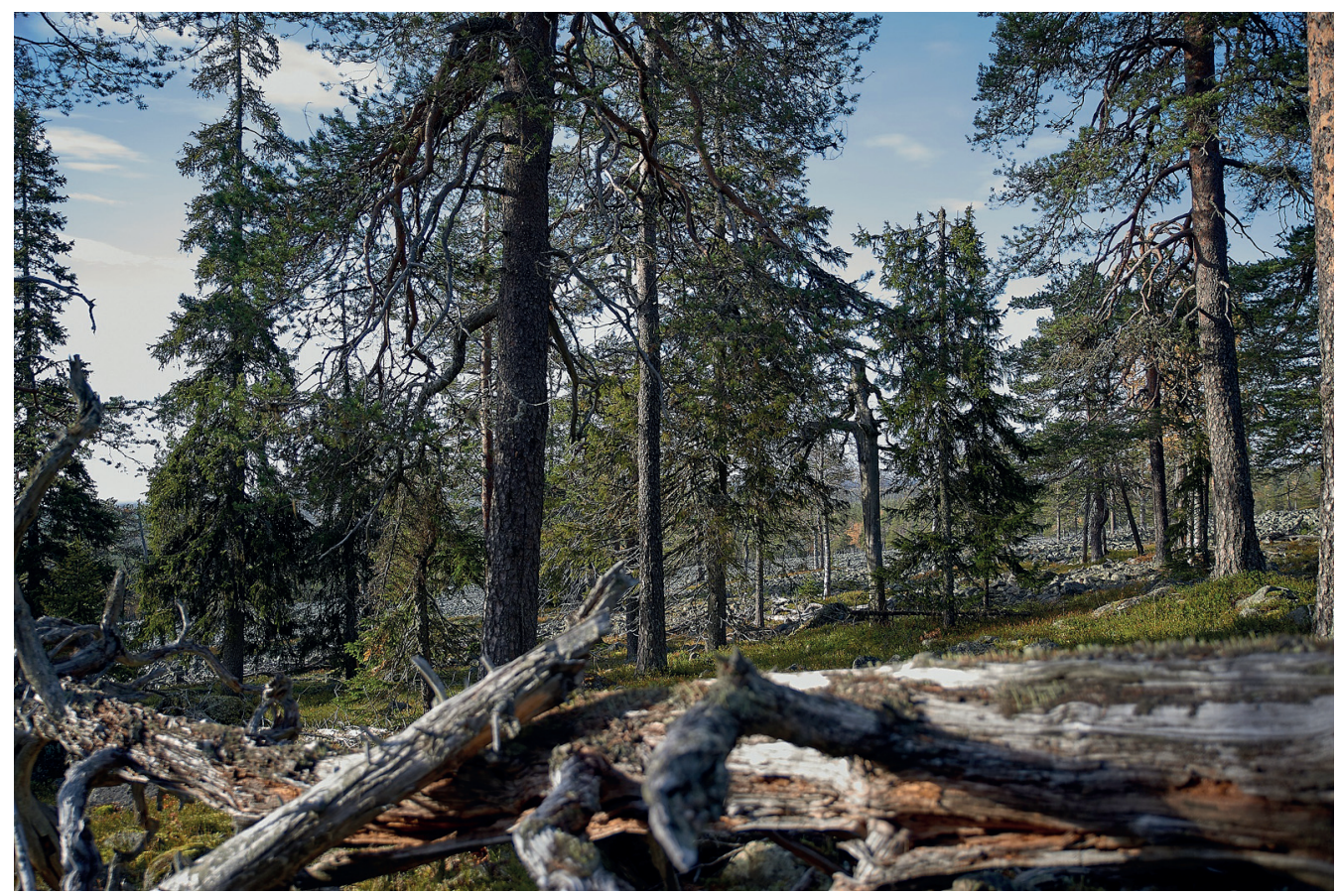

Fig. 4. The habitat of Athelia singularis in Pisavaara Strict Nature Reserve. Photo: A. Kroschel

Examined specimens of Athelia fibulata: FINLAND, TAVASTIA AUSTRALIS, Tammela, Torronsuo National Park, Piippurinsuo E, UCS 67410:33222, 27 Oct 1999, leg. HK 16664 (H.K.), in 1997 burned mixed forest, on charred Betula sp. bark; LAPPONIA KITTILENSIS, Muonio, Pallas-Yllästunturi National Park, Sammaltunturi SE slope, UCS 7544:3380, 21 Sep 1995, leg. HK 12533a (H.K.) \& V.A. Mukhin, Picea abies ssp. obovata (Ledeb.) Domin dominated old-growth forest, on dead Phellinus ferrugineofuscus (P. Karst.) Bourd./Picea abies ssp. obovata; RUSSIA, KRASNOYARSK KRAY, S of Abakan, Erkagi, $52^{\circ} 51^{\prime} \mathrm{N}, 093^{\circ} 15^{\prime} \mathrm{E}$, alt. 1200 m, 14 Aug 2011, leg. HK 25123 (H.K.), old-growth forest with Abies sibirica Ledeb., Pinus cembra ssp. sibirica (Du Tour) Krylov plus tall grasses and herbs, on corticated Abies twig, diameter $0.1-0.6 \mathrm{~cm}$, decay stage 1 .

Notes. Athelia singularis is collected from Norway, Russia, Sweden, United Kingdom (Bernicchia \& Gorjón 2010, as A. fuciformis (Wakef.) Burds.) and the United States (MyCoPortal 2015). It grows mainly on coniferous wood (Larix, Pinus, Sequoia) (Jülich 1972; MyCoPortal 2015), but the type specimen grew on Betula ermanii Cham. in Kamchatka, Russian Far East (Parmasto 1967).

Leptosporomyces mundus (H.S. Jacks. \& Dearden) Jülich, Willdenowia, Beih. 7: 200, 1972.

Fig. 5

Fruit body resupinate, pellicular (athelioid), smooth to the naked eye, porose under the lens $(\times 50)$, relatively thin, easily detachable, white, margin thinning out, not differentiated. 

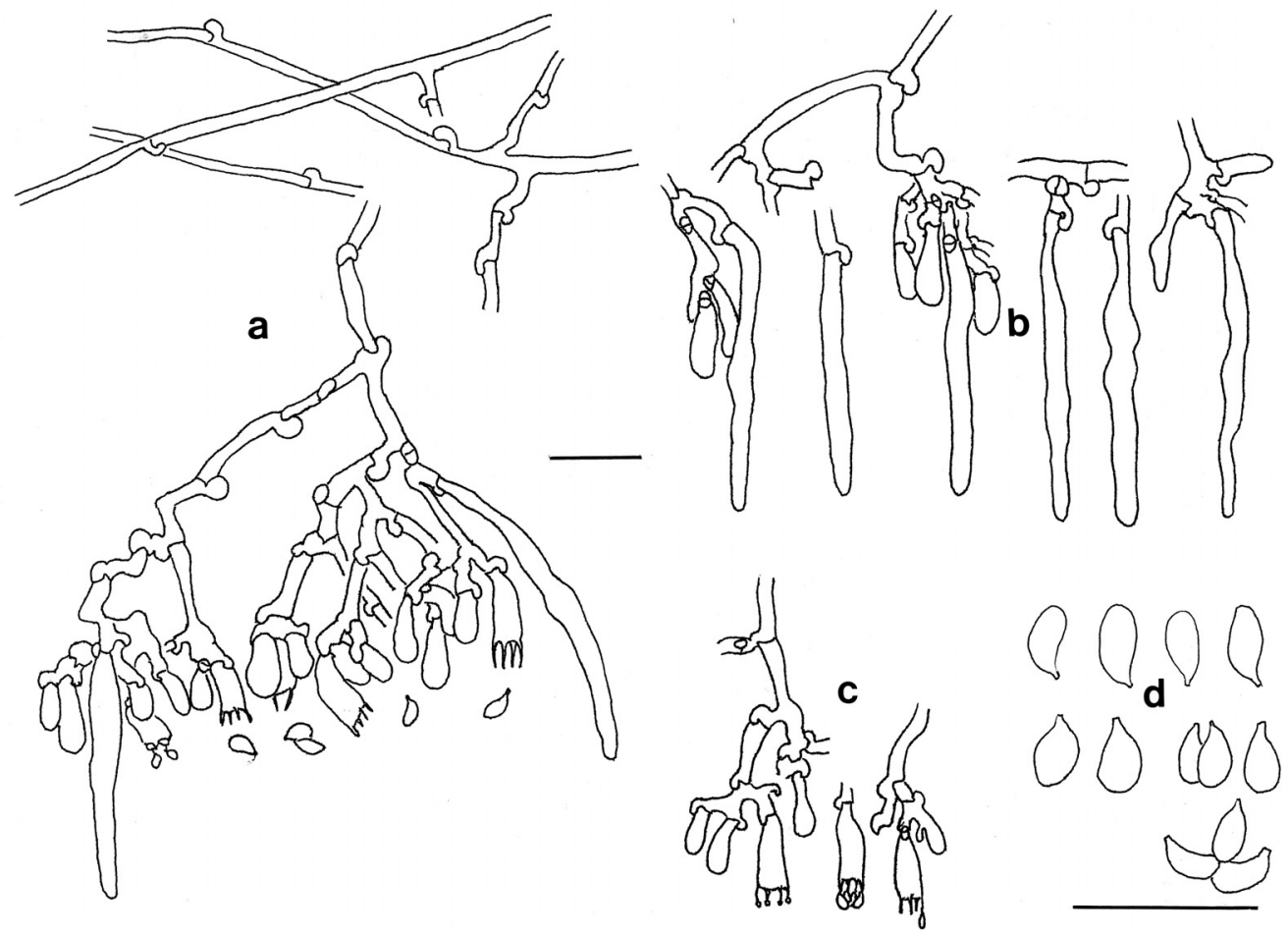

Fig. 5. Leptosporomyces mundus: a) section through basidiocarp, b) cystidia, c) basidioles and basidia, d) spores (Kulju 102/15). Scale bars $=10 \mu \mathrm{m}$

Hyphal system monomitic, hyphae clamped, narrow, CB-, MLZ-. Subicular hyphae thin-walled, CB-, MLZ-, sparingly clamped, 1-2(-3) $\mu \mathrm{m}$ in diameter; subhymenial hyphae richly branched, thin-walled, $1-2 \mu \mathrm{m}$ wide. Cystidia abundant, basally clamped, thinwalled, cylindrical, tapering towards the blunt apex, 25-35(-40) $\times(2.5-) 3-3.5(-4) \mu \mathrm{m}$, projecting $10-18 \mu \mathrm{m}$ over the basidia. Basidia subcylindrical-subclavate, thin-walled, basally clamped, 7-11(-16) $\times 3-3.5(-4) \mu \mathrm{m}$, with four needle-like, up to $3 \mu \mathrm{m}$ long sterigmata. Spores ellipsoid, subfusiform or pip-shaped, thin-walled, CB-, MLZ-, 3-3.5(-3.8) $\times 1.7-$ $2.1 \mu \mathrm{m}, \mathrm{L}=3.3 \mu \mathrm{m}, \mathrm{W}=1.9 \mu \mathrm{m}, \mathrm{Q}=1.6-2.1, \mathrm{Q}^{*}=1.8$, with a prominent apiculus.

Specimen examined-FINLAND, OSTROBOTTNIA ULTIMA, Rovaniemi, Pisavaara Strict Nature Reserve, Teerilamu, UCS 7358035:3415596, alt. 210 m, 12 Oct 2015, leg. MK 102/15 (OULU, H.K.) \& AK, det. HK 2015. Fruit body grew underneath of the decorticated trunk of Pinus sylvestris (diameter $27 \mathrm{~cm}$, decay stage 4). The length of the fruit body was $70 \mathrm{~cm}$. The habitat was a stony old-growth mesic heath forest.

Notes. Leptosporomyces mundus is easy to identify. The narrow hyphae, very small basidia, cystidia and spore size and shape make it a characteristic species. Some of the clamps are large if compared to the thickness of the hyphae (see also Jülich 1972, p. 203) and the shape of the spores is very diagnostic with the large apicular region. L. mundus is fairly little collected but known distribution covers the Northern Hemisphere: Russia, 
Sweden, Norway, Austria, the United States and Canada. Recorded host trees have been conifers: Abies magnifica A. Murray, Picea engelmannii Parry ex Engelm., P. rubens Sarg. and Tsuga mertensiana (Bong.) Carr. (Jülich 1972; Maurer et al. 2003, 2014; Bates 2006; Bernicchia \& Gorjón 2010; Dyntaxa 2013; MyCoPortal 2015; Anonymous 2016).

\section{Conclusions}

According to the published records of Athelia singularis and Leptosporomyces mundus, both are globally rare and little collected species. All records are from the Northern Hemisphere and fruit bodies have been found mostly from dead coniferous trees. It is interesting that both of these species were found from one of the most diverse forest areas in Finland with high degree of naturalness. Even more interesting is that on 12 October 2015 MK collected only a few specimens two of which were new species to Finland.

The occurrence and distribution of corticioids are still inadequately known in Finland, especially in remote regions such as Lapland or the archipelagos of the Baltic Sea. It is obvious that dozens of corticioid and other aphyllophoroid species can still be found in Finland; some new species are found every year (e.g. Niemelä et al. 2012; Spirin et al. 2013, 2015).

To reveal an accurate diversity of Finnish aphyllophoroid funga, more effort should be put into surveys. More attention should be paid particularly into rare habitats and unusual substrata with potential specialist species (e.g. Niemelä et al. 2002; Yurchenko 2006). Furthermore, often overlooked the smallest fractions of woody debris provide substrata for a wide range of corticioids (Nordén et al. 2004; Juutilainen et al. 2011).

Acknowledgements. We are thankful to Axel Kroschel for participating in the field excursion in Pisavaara and giving the photograph to this article, and to Sanna-Mari Kunttu for drawing the map.

\section{References}

Ahti, T., Hämet-Ahti, L. \& Jalas, J. 1968. Vegetation zones and their sections in northwestern Europe. Annales Botanici Fennici 5: 169-211.

Anonymous. 2014. [Biogeographical provinces of Finland]. Finnish Museum of Natural History. http:// www.luomus.fi/fi/eliomaakunnat. (In Finnish) (Accessed 11 Jan 2016)

Anonymous. 2016. Skyggespindelhinne Leptosporomyces mundus (H.S. Jacks. \& Dearden) Jülich. Norwegian Biodiversity Information Centre. http://data.artsdatabanken.no/ScientificName/55810. (Accessed 12 Jan 2016)

Bates, S.T. 2006. A preliminary checklist of Arizona macrofungi. - Canotia 2(2): 47-78.

Bernicchia, A. \& Gorjón, S.P. 2010. Corticiaceae s.1. - Fungi Europaei 12: 1-1008.

Dyntaxa. 2013. Swedish Taxonomic Database. Swedish University of Agricultural Sciences. http://www. dyntaxa.se. (Accessed 12 Jan 2016)

Eriksson, J. \& Strid, A. 1969. Studies in the Aphyllophorales (Basidiomycetes) of Northern Finland. - Annales Universitatis Turkuensis A II 40: 112-158. 
Heikinheimo, O. \& Raatikainen, M. 1981. [Grid references and names of localities in the recording of biological finds in Finland]. - Notulae Entomologicae 61: 133-154. (In Finnish with English summary)

Hokkanen, M., Aapala, K. \& Alanen, A. 2005. [National plan for monitoring at restoration and management sites]. - Metsähallituksen luonnonsuojelujulkaisuja B76: 1-85. (In Finnish with English summary) Jülich, W. 1972. Monographie der Athelieae (Corticiaceae, Basidiomycetes). - Wildenowia Beiheft 7: 1-283. Juntunen, M.-L. (ed.) 2014. [Forest biodiversity and health]. - In: A. Peltola (ed.). Statistical yearbook of forestry 2014. Pp. 79-104. Finnish Forest Research Institute, Tampere. (In Finnish with English summary)

Juutilainen, K., Halme, P., Kotiranta, H. \& Mönkkönen, M. 2011. Size matters in studies of dead wood and wood-inhabiting fungi. - Fungal Ecology 4: 342-349. doi: 10.1016/j.funeco.2011.05.004

Kotiranta, H. \& Larsson, K.-H. 2013. Sistotrema luteoviride sp. nov. (Cantharellales, Basidiomycota) from Finland. - Acta Mycologica 48: 219-222. doi: 10.5586/am.2013.023

Kotiranta, H. \& Shiryaev, A. 2013. Notes on aphyllophoroid fungi (Basidiomycota) in Kevo, collected in 2009. - Kevo Notes 14: 1-22.

Kotiranta, H., Saarenoksa, R. \& Kytövuori, I. 2009. Aphyllophoroid fungi of Finland. A check-list with ecology, distribution, and threat categories. - Norrlinia 19: 1-223.

Kotiranta, H., Larsson, K.-H., Saarenoksa, R. \& Kulju, M. 2011. Tretomyces gen. novum, Byssocorticium caeruleum sp. nova, and new combinations in Dendrothele and Pseudomerulius (Basidiomycota). Annales Botanici Fennici 48: 37-48. doi: 10.5735/085.048.0106

Kunttu, P., Kulju, M. \& Kotiranta, H. 2010. Rare corticioid fungi in Finland - records of new and little collected species (Basidiomycota). - Karstenia 50: 35-44.

Kunttu, P., Kulju, M., Pennanen, J., Kotiranta, H. \& Halme, P. 2011. Additions to the Finnish aphyllophoroid fungi. - Folia Cryptogamica Estonica 48: 25-30.

Kunttu, P., Kulju, M. \& Kotiranta, H. 2012. New national and regional biological records for Finland 2. Contributions to the Finnish aphyllophoroid funga (Basidiomycota). - Memoranda Societatis pro Fauna et Flora Fennica 88: 61-66.

Maurer, W., Dämon, W., Forstinger, H. \& Scheuer, C. 2003. Holzabbauende Pilze der Steiermark, IV. Mitteilungen des Naturwissenschaftlichen Vereines für Steiermark 133: 11-36.

Maurer, W., Friebes, G. \& Scheuer, C. 2014. Pilze auf Holz - Ökologie und Verbreitung in der Steiermark (Artenliste und Nachträge). - Joannea Botanik 11: 35-75.

MyCoPortal 2015. The Mycology Collections data Portal (MyCoPortal). http://mycoportal.org. (Accessed 11 Jan 2016)

Niemelä, T., Wallenius, T. \& Kotiranta, H. 2002. The kelo tree, a vanishing substrate of specified woodinhabiting fungi. - Polish Botanical Journal 47: 91-101.

Niemelä, T., Kinnunen, J. \& Kotiranta, H. 2005. [Polypores of the Pisavaara Strict Nature Reserve and Korouoman-Jäniskaira Nature Reserve]. - Metsähallituksen luonnonsuojelujulkaisuja A 150, Metsähallitus. 51 pp. (In Finnish with English summary)

Niemelä, T., Miettinen, O. \& Manninen, O. 2012. Aurantiporus priscus (Basidiomycota), a new polypore from old fallen conifer trees. - Annales Botanici Fennici 49: 201-205. doi: 10.5735/085.049.0308

Nordén, B., Ryberga, M., Götmark, F. \& Olausson, B. 2004. Relative importance of coarse and fine woody debris for the diversity of wood-inhabiting fungi in temperate broadleaf forests. - Biological Conservation 117: 1-10. doi: 10.1016/S0006-3207(03)00235-0 
Parmasto, E. 1967. Corticiaceae U.R.S.S. IV. Descriptiones taxorum novarum. Combinationes novae. Eesti NSV Teaduste Akadeemia Toimetised 16: 377-394.

Renvall, P. 1995. Community structure and dynamics of wood-rotting Basidiomycetes on decomposing conifer trunks in Northern Finland. - Karstenia 35: 1-51.

Spirin, V., Miettinen, O., Pennanen, J., Kotiranta, H. \& Niemelä, T. 2013. Antrodia hyalina, a new polypore from Russia, and A. leucaena, new to Europe. - Mycological Progress 12: 53-61. doi: 10.1007/s11557-012-0815-0.

Spirin, V., Runnel, K., Vlasák, J., Miettinen, O. \& Póldmaa, K. 2015. Species diversity in the Antrodia crassa group (Polyporales, Basidiomycota). - Fungal Biology 119: 1291-1310. doi: 10.1016/j. funbio.2015.09.008

Stokland, J.N. \& Sippola, A.-L. 2004. Monitoring protocol for wood-inhabiting fungi in the Alberta Biodiversity Monitoring Program. Alberta Biodiversity Monitoring Program. 58 pp.

Teivainen, L. 1949. Pisavaaran luonnonpuiston metsäkasvillisuudesta ja kasvistosta. [Zur Waldvegetation und Flora des Naturschutzgebietes Pisavaara]. - Silva Fennica 65: 1-34. (In Finnish with German summary) doi:10.14214/sf.a13978

Yurchenko, E.O. 2006. Natural substrata for corticioid fungi. - Acta Mycologica 42: 113-124. 